\title{
The proteome of the calcified layer organic matrix of turkey (Meleagris gallopavo) eggshell
}

\author{
Karlheinz Mann ${ }^{*}$ and Matthias Mann
}

\begin{abstract}
Background: Chicken eggshell mineralization is a prominent model for biomineralization not only because of its importance for avian reproduction but also because of the commercial interest associated with eggshell quality. An analysis and comparison of the protein constituents of eggshells of several species would contribute to a better understanding of the shell mineralization process. The recent publication of the turkey genome sequence now provides a basis for the in-depth analysis of the turkey eggshell proteome.

Results: Proteomic analysis of turkey acid-soluble and acid-insoluble organic eggshell matrix yielded 697 identified proteins/protein groups. However, intensity-based absolute quantification (iBAQ) results indicated that the 47 most abundant identified proteins already constituted $95 \%$ of the total turkey eggshell matrix proteome. Forty-four of these proteins were also identified in chicken eggshell matrix previously. Despite these similarities there were important and unexpected differences. While ovocleidin-116 and ovocalyxin-36 were major proteins constituting approximately $37 \%$ of the identified proteome, other members of the group of so-called eggshell-specific proteins were not identified. Thus ovocalyxin-21 and ovocalyxin-32 were missing among matrix proteins. Conversely, major turkey eggshell proteins were not detected in chicken, such as the bone protein periostin, the mammalian counterpart of which is involved in many aspects of bone metabolism and which represented $10-11 \%$ of the total identified proteome.

Conclusions: Even members of the same avian family show important differences in eggshell matrix composition and more studies on the proteome and the transcriptome level will be necessary to identify a common toolkit of eggshell mineralization and to work out species differences among functional eggshell protein sets and their role in eggshell production.
\end{abstract}

\section{Background}

The avian eggshell is a bioceramic formed of calcium carbonate and an organic matrix pervading and enveloping the calcite crystals. Eggshell formation is the last step of egg production, a process most comprehensively studied in the chicken due to its commercial importance [1,2]. Egg production starts in the ovary by massive yolk accumulation for six to ten days. Most yolk components are produced in the liver, secreted into the blood stream and transported to the ovary where they are taken up by receptor-mediated transport at the oolemma, the plasma membrane of the egg cell [3]. After ovulation the egg, the bulk of which is yolk covered by a proteinaceous inner vitelline membrane, enters

\footnotetext{
* Correspondence: mann@biochem.mpg.de

Max-Planck-Institut für Biochemie, Abteilung Proteomics und Signaltransduktion, D-82152, Martinsried, Am Klopferspitz 18, Germany
}

the oviduct to start an approximately $22 \mathrm{~h}$-long journey driven by peristaltic movements of the oviduct wall. In the first section of the oviduct, the infundibulum, the egg is covered by the outer vitelline membrane. Egg white (albumen) production takes place in the next section of the oviduct, the magnum. Eggshell formation starts in the white isthmus by assembly of the eggshell membranes from soluble components secreted by cells lining the oviduct. First small calcite accretions form on specialized, regularly spaced nucleation sites on the external shell in the red isthmus [4]. Bulk mineralization takes place in the eggshell gland (uterus), where the egg stays for 16-17 h. The final step in eggshell assembly is the deposition of the cuticle, which also covers the openings of eggshell pores traversing the calcified layer. Eggshell calcification is thought to be controlled by matrix proteins secreted by epithelial cells lining isthmus and 
uterus [5-7]. However, our previous proteomic analyses of the soluble proteome of the chicken calcified eggshell layer $[8,9]$ indicated that the matrix does not only contain proteins produced by the shell gland epithelium but also proteins produced and secreted in other sections of the oviduct. Apparently leftovers of the assembly processes along the egg production line migrate with the egg to end up in the uterus fluid where they are eventually incorporated into the growing calcitic layer. Several such proteins, especially the major egg white proteins ovalbumin [10], lysozyme [11] and ovotransferrin [12] were shown by immunohistochemical methods to reside in the intra-crystalline matrix itself and not to be just surface contaminants. This location was also confirmed for osteopontin, a protein previously identified in bone, but also secreted in the eggshell gland triggered by the entry of the egg and is therefore an example of a protein occurring in different biomineral systems of one organism [13]. However, although egg white proteins may weakly influence calcium carbonate crystallization in vitro [11,12,14,15], their role, if any, in eggshell mineralization remains unclear. In addition to egg proteins the matrix proteome contained basement membrane components, endoplasmatic reticulum residents, Golgi complex proteins, and other intracellular compartments. These may have reached the oviduct fluid as byproducts of secretion or may have been released by damaged cells of the oviduct epithelium. In total, the soluble proteome of the mineralized layer, the thickest eggshell compartment, comprised more than 520 proteins $[8,9]$. Further proteomic studies of insoluble proteins of the calcified layer and the cuticle [16] and solubilized cuticle [17] contributed several interesting new proteins to the overall chicken eggshell proteome. This unexpected complexity of the eggshell proteome raised the problem of how to discern between matrix proteins functioning in matrix assembly and calcification and a background of non-functional proteins. Because birds are not as easily accessible to genetic manipulation as unicellular or some invertebrate species, one has to resort to more practicable methods.

The concept that functional eggshell proteins should be produced in the eggshell gland has stimulated gene expression studies with microarrays comparing differential expression between eggshell gland tissue of juvenile and sexually mature hens [18] and between eggshell gland tissue and tissues of other oviduct sections [19]. Of these studies, the second one may be more relevant to the identification of eggshell proteins, because it focused on the eggshell gland during deposition of the eggshell. Altogether 605 transcripts were highly expressed in uterine tissue as compared to other oviduct sections and 437 corresponded to known proteins present in protein sequence databases. Of these, 52 corresponded to matrix constituents identified by proteomics or protein biochemical methods previously. However, many of these transcripts or corresponding proteins are not likely to play a role in eggshell production, because the list also contains such proteins as tubulin, actin, glyceraldehyde-3-P-dehydrogenase or ezrin. A disadvantage of such transcriptomic studies is that they will not recognize major eggshell proteins such as ovotransferrin, ovalbumin or serum albumin, which are not produced in the eggshell gland but may nevertheless influence eggshell mineralization and eggshell properties in some way $[11,12,14,15]$. Another possible way to identify functionally important eggshell proteins, and the one we pursue here, is the comparison of eggshell matrices of different avian species.

Mass spectrometry (MS)-based in-depth and highthroughput studies depend on the availability of comprehensive sequence databases created by genome sequencing projects. The first available avian genome sequence was that of chicken [20] followed by zebra finch [21] and turkey [22] genome sequences recently. For the present study we chose the turkey eggshell because turkey belongs to the same family as chicken (Phasianidae) and has a very similar genome [22,23]. The present proteomic analysis of the turkey calcified eggshell layer acid-soluble and acid-insoluble proteins showed many similarities, but also unexpected differences, between chicken and turkey eggshell proteomes.

\section{Materials and methods}

\section{Preparation of proteins and peptides}

Turkey eggshells (strains Converter and Big 6) were obtained from Putenzucht Miko GmbH, A-4871 Zipf, Austria. These were fertilized, but not incubated eggs. The empty shells of five eggs of each strain were washed under tap water and then cleaned in 5\% EDTA for $60 \mathrm{~min}$ at room temperature to facilitate mechanical removal of membranes, cuticle and attached contaminants. The membranes were peeled off and the cuticles were removed by rubbing under flowing de-ionized water. The pieces of calcified eggshell were washed with water, dried and demineralized in 10\% acetic acid ( $1 \mathrm{~g}$ of shell/ $20 \mathrm{ml}$ ) overnight in the cold room. The suspension was centrifuged for $1 \mathrm{~h}$ at $4^{\circ} \mathrm{C}$ and $12000 \mathrm{~g}_{\mathrm{av}}$ to separate acidsoluble from acid-insoluble matrix. The pellets were washed three times by re-suspension in 10vol $10 \%$ acetic acid, centrifugation at $4^{\circ} \mathrm{C}$ and $12000 \mathrm{~g}_{\mathrm{av}}$ for $30 \mathrm{~min}$, and lyophilized. Supernatants were successively dialyzed against $3 \times 10 \mathrm{vol} 10 \%$ acetic acid and $2 \times 10 \mathrm{vol} 5 \%$ acetic acid at $4-6^{\circ} \mathrm{C}$ (Spectra/Por 6 dialysis membrane, molecular weight cut-off 2000; Spectrum Europe, Breda, The Netherlands) and lyophilized.

Proteins were separated by SDS-PAGE using pre-cast 4-12\% Novex Bis-Tris gels in MES buffer, using reagents 
and protocols supplied by the manufacturer (Invitrogen, Carlsbad, CA), except that $1 \% \beta$-mercaptoethanol was used as reducing agent in the sample buffer. The sample was suspended in $20 \mu \mathrm{l}$ sample buffer $/ 100 \mu \mathrm{g}$ of matrix, heated to $70^{\circ} \mathrm{C}$ for $10 \mathrm{~min}$, and centrifuged to remove sample buffer-insoluble material. Three lanes were loaded with $80 \mu \mathrm{g}$ of organic matrix in each of three separate experiments per strain and fraction. Gels were stained with colloidal Coomassie (Invitrogen) after electrophoresis, and cut into suitable slices for in-gel reduction, carbamidomethylation and digestion with trypsin as described [24]. The molecular weight marker was Novex Sharp pre-stained (Invitrogen). The eluted peptides were cleaned with C18 Stage Tips [25] before mass spectrometric analysis.

\section{LC-MS and data analysis}

Peptide mixtures were analyzed by on-line nanoflow liquid chromatography using the EASY-nLC 1000 system (Proxeon Biosystems, Odense, Denmark, now part of Thermo Fisher Scientific) with $20 \mathrm{~cm}$ capillary columns of an internal diameter of $75 \mu \mathrm{m}$ filled with $1.8 \mu \mathrm{m}$ Reprosil-Pur C18-AQ resin (Dr. Maisch GmbH, Ammerbuch-Entringen, Germany). Peptides were eluted with a linear gradient from 5-30\% buffer B (80\% acetonitrile in $0.1 \%$ formic acid) for $100 \mathrm{~min}, 30-60 \%$ B for 12 $\mathrm{min}$ and $80-95 \% \mathrm{~B}$ for $8 \mathrm{~min}$ at a flow rate of $250 \mathrm{nl} / \mathrm{min}$. The eluate was electro-sprayed into an Orbitrap Elite (Thermo Fisher Scientific, Bremen, Germany) using a Proxeon nanoelectrospray ion source. The Orbitrap Elite was operated in a HCD top 10 mode essentially as described [26,27]. The resolution was 120,000 for full scans and 15,000 for fragments (both specified at $\mathrm{m} / \mathrm{z}$ 400). Ion target values were $1 \mathrm{e} 6$ and $5 \mathrm{e} 4 \mathrm{~ms}$, respectively. Exclusion time was $90 \mathrm{sec}$. Raw files were processed using the Andromeda search engine-based version 1.3.9.3 of MaxQuant (http://www.maxquant.org/) with enabled second peptide, iBAQ and match between runs (match time window $0.5 \mathrm{~min}$; alignment time window 20 min) options [28-30]. For protein identification the ENSEMBL turkey protein database from release 66, 2012, (http://www.ensembl.org/info/data/ttp/index.html) was downloaded and combined with the reversed sequences and sequences of common contaminants, such as human keratins. Carbamidomethylation was set as fixed modification. Variable modifications were oxidation $(\mathrm{M})$, $\mathrm{N}$-acetyl (protein) and pyro-Glu/Gln (N-term). The initial mass tolerance for full scans was $7 \mathrm{ppm}$ and $20 \mathrm{ppm}$ for MS/MS. Two missed cleavages were allowed and the minimal length required for a peptide was seven amino acids. The peptide and protein false discovery rates (FDR) were set to 0.01 . The maximal posterior error probability (PEP), which is the individual probability of each peptide to be a false hit considering identification score and peptide length, was set to 0.01. Two sequence-unique peptides (sum of sequence-unique peptides in acid-soluble and acidinsoluble fractions of six technical replicates forming one biological replicate) occurring at least three times in total in two different technical replicates were required for highconfidence protein identifications. Identifications with only two sequence-unique peptides were routinely validated using the MaxQuant Expert System software [31] considering the assignment of major peaks, occurrence of uninterrupted $y$ - or b-ion series of at least four consecutive amino acids, preferred cleavages $\mathrm{N}$-terminal to proline bonds, the possible presence of $\mathrm{a} 2 / \mathrm{b} 2$ ion pairs and immonium ions, and mass accuracy. The iBAQ (intensity-based absolute quantification) [32] option of MaxQuant was used to calculate, based on the sum of peak intensities, the approximate share of each protein in the total proteome.

Sequence database searches were performed with FASTA (http://www.ebi.ac.uk/Tools/sss/fasta/) [33] against current releases of Uniprot Knowledgebase (UniProtKB) and International Protein Index (IPI). Other bioinformatics tools used were clustalW2 for sequence alignments (http://www.ebi.ac.uk/Tools/msa/clustalw2/), InterProScan (http://www.ebi.ac.uk/Tools/pfa/iprscan/) [34] for domain predictions, SignalP 4.1 (http://www.cbs.dtu.dk/services/SignalP/) [35] for signal sequence prediction, and the Venn diagram plotter (http://omics.pnl.gov/software/VennDiagramPlotter.php) for preparing Venn diagrams.

\section{Results and discussion}

For this study we used two biological replicates each consisting of the pooled washed shell calcified layers of five eggs of either strain Converter (biological replicate A) or strain Big6 (biological replicate B). Each of these biological replicates was analyzed in six technical replicates, three for the acid-soluble fraction and three for the acid-insoluble fraction. Matrix yields were approximately $8 \mathrm{mg}$ of acid-soluble matrix and $16 \mathrm{mg}$ of acidinsoluble matrix per $\mathrm{g}$ of dry shell calcified layer, together constituting approximately $2.5 \%$ of the total shell weight. No differences were detected in PAGE patterns of samples from different strains (not shown). Acidsoluble eggshell matrix and acid-insoluble matrix were analyzed separately. For each technical replicate three identical PAGE lanes were cut into 18 slices for in-gel digestion (Figure 1). MS analysis of the eluted peptides produced a total of 216 raw files. Technical replicate groups were analyzed with MaxQuant, first separately, then after combining results of acid-soluble and acidinsoluble fractions of each strain. After grouping obvious fragments of identical proteins and almost identical proteins together, pool A (strain Converter) yielded 555 protein groups and pool B (strain Big 6) 647 protein groups, with an overlap of 505 protein groups (Figure 2A). Almost all of the protein groups identified in only one pool 


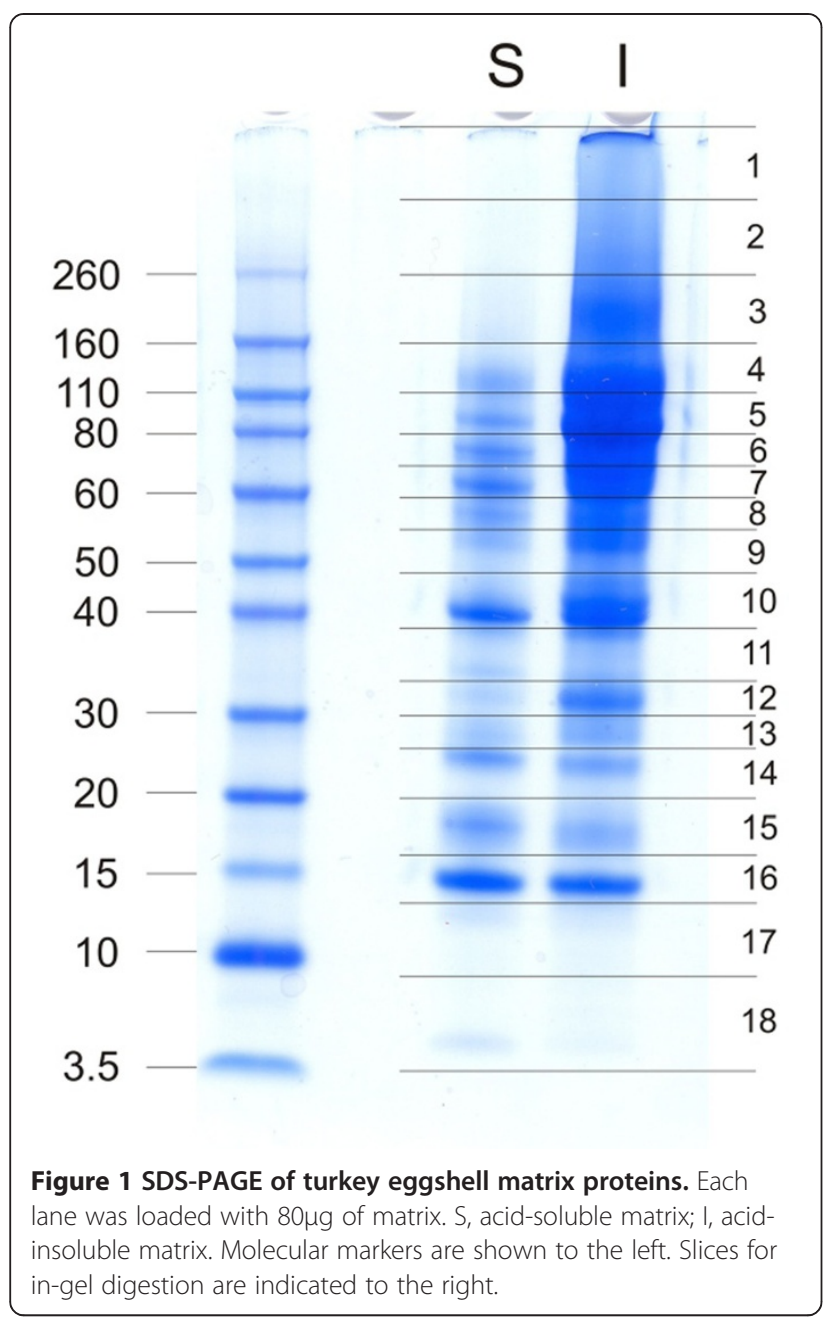

were of low or very low abundance, each protein representing between $<0.0001$ to $<0.01 \%$ of the total proteome as judged by their iBAQ values. Furthermore, most of these proteins were also identified in the respective other pool but below statistical acceptance thresholds. Therefore these differences likely did not represent differences between strains, but rather experimental variation. The combined proteomes yielded 697 protein groups (Additional file 1: Table S1) that may represent a slightly lower number of proteins because not all fragments of identical proteins distributed over different database entries may have been identified unequivocally. This was more than the sum of different proteins identified in the acid-soluble shell proteome [8,9], the insoluble shell proteome [16] and the cuticle [17] of the chicken eggshell (Figure 2B), a finding that may also reflect technical progress. The overlap between total chicken and turkey eggshell proteomes was $52 \%$ and increased to $85 \%$ if only turkey proteins of $>0.01 \%$ of the total proteome (172 proteins) were considered, and to $94 \%$ with proteins of greater than $0.1 \%$ abundance $(47$

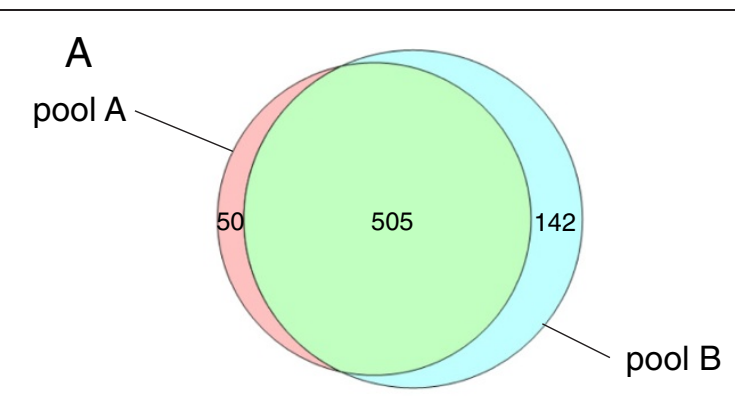

B

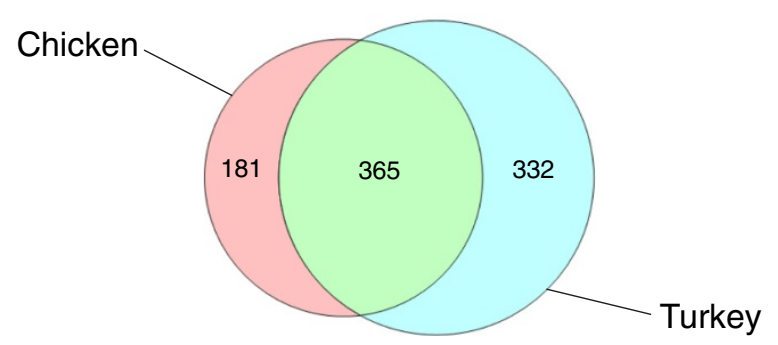

Figure 2 Comparison of turkey biological replicate proteomes (A) chicken and turkey eggshell proteomes (B). The number of identified chicken eggshell proteins were compiled from $[8,9,16,17]$ and cover acid-soluble proteins of the calcified layer $[8,9]$, insoluble proteins of the calcified shell [16], and cuticle proteins [17].

proteins). This indicates that much of the differences occurred among the low and very low-abundance proteins. The numerical difference between combined chicken eggshell proteins and turkey eggshell proteins was 151 proteins (protein groups). This increase may be attributable to a large part to developments in mass spectrometry instrumentation (FT-ICR [8] versus the much faster Orbitrap Elite, this study). However, the greater number of technical replicates and the analysis of both, acidsoluble and acid-insoluble fraction, may also have contributed. The complete lists of identified protein groups including those not accepted for Additional file 1: Table S1 are contained in Additional file 2: Table S2 ProteinGroups pool A, and Additional file 3: Table S3 ProteinGroups pool B. The identified peptides are listed in Additional file 4: Table S4 Peptides pool A and Additional file 5: Table S5 Peptides pool B. These files also contain additional accession numbers for groups with more than one protein, numbers of total, razor and sequence-unique peptides, their distribution over gel sections, iBAQ intensities, peptide sequences, and other relevant data not only for accepted identifications but also for identifications with only one peptide or two peptides in only one technical replicate.

Of the 697 protein groups 122 were identified only in acid-soluble fractions and 20 only in acid-insoluble fractions (Additional file 1: Table S1). Most of these were identified in shells of only one turkey strain at low 
abundance $(<0.001 \%)$ and may not be due to true solubility preferences but experimental variation. However, 38 proteins were identified in one fraction of both biological replicates and may therefore reflect real differences in distribution among solubility fractions (Additional file 1: Table S1). This may especially be true for proteins identified with more than three sequence-unique peptides or an abundance of $>0.001 \%$, such as the antimicrobial peptide NK-lysine (H9H1A3_MELGA), the possibly extracellular ribonuclease G1NAU2_MELGA, the protein similar to Cys-rich secretory protein 3 contained in entry G1NN67_MELGA, or galectin-3 (G1NLL4_MELGA).

Similar to the chicken eggshell proteome, the turkey eggshell proteome contained many proteins occurring in other egg compartments, especially the egg white. These are likely leftovers of egg assembly that migrate together with the egg from the site of their secretion into the oviduct lumen to the eggshell gland [8]. Other proteins may have reached the oviduct fluid as by-products of secretion, shedding of extracellular domains of membrane proteins, or may have been released by damaged epithelial cells. This mixture of proteins is then supplemented with proteins specifically secreted from uterus epithelia and may be inserted into the growing eggshell during mineralization.

When looking for functional eggshell proteins, an obvious choice is to inspect the major proteins, although minor proteins can of course also affect matrix assembly and mineralization, especially if they have catalytic properties. In previous studies we discerned major proteins from minor ones using the exponentially modified protein abundance index (emPAI), a quantification method relying on spectral counts and relating the number of identified unique parent ions to the number of theoretically possible peptides [36]. Although in principle well suited for the purpose of identifying major proteins, the results are not particularly intuitive and the division into abundance groups as practiced before is somewhat arbitrary [8]. In the present study we therefore used the more refined iBAQ procedure [32] as implemented in recent MaxQuant versions. This method is based on peak intensities of identified peptides and these can be normalized to the sum of all intensities yielding the percentage of each component in relation to the total proteome. This showed that 47 major proteins, or protein groups, with an individual percentage of $>0.1$ constituted approximately $95 \%$ of the total identified turkey eggshell proteome. Of these 47 proteins we previously identified 44 (94\%) in the chicken eggshell proteome and 24 were among the 50 most abundant of the chicken matrix proteins (Table 1). Furthermore, the messages of 11 of them were previously found to be up-regulated in epithelia of egg-containing uterus in different transcriptomic studies (Table 1). However, there were also some unexpected differences as detailed below.

\section{Ovocleidins and ovocalyxins ("eggshell-specific" proteins)}

By far the most abundant protein in the identified turkey eggshell proteome was ovocleidin-116 (OC-116) (Table 1). As frequently observed for major proteins, OC-116 was identified with hundreds of peptides all over the PAGE gradient (Additional file 2: Table S2 and Additional file 3: Table S3). However, we found the highest concentration in slice 5 (Figure 1) corresponding to a $\mathrm{M}_{\mathrm{r}}$ of 80 to $110 \mathrm{kDa}$. The presence of OC-116 fragments, observed in chicken matrix preparations [37], could also have contributed to the PAGE pattern and the resulting peptide distribution. Some representative spectra identifying and distinguishing the turkey protein are shown in Figure 3. OC-116 was first detected in chicken eggshell as the core protein of a proteoglycan with a molecular mass of approximately 120kDa [38] and was subsequently characterized by molecular cloning and sequencing [37,39]. A substantial fraction of it occurs in the eggshell matrix without attached glycosaminoglycan chains, but in an N-glycosylated form [40]. In the chicken eggshell matrix we previously showed that OC-116 was one of the most abundant proteins of the acid-soluble proteome [8] and phosphoproteome [9]. OC-116 was first described as an eggshell-specific protein [39] but was subsequently also identified in egg yolk [41], the vitelline membrane [42] and egg white [43]. Interestingly, however, it was also identified in chicken bone [44] and is expressed in chicken osteoblasts and osteocytes during bone development and mineralization [45], indicating some similarities between bone and eggshell mineralization. The supposed mammalian homolog of OC-116, matrix extracellular phosphoglycoprotein (MEPE) [45], was shown to regulate bone formation, for instance by inhibiting growth plate cartilage mineralization [46]. In comparison to chicken OC-116 the turkey protein sequence (ENSMGAP00000007641/G1N6E1_MELGA) lacked approximately 250 amino acids (aa) at the Cterminus. Sequence identity in the remaining overlap of approximately 500aa was $80 \%$. Consequently only four of the 40 sequence-unique peptides identified matched to chicken and turkey sequences. Database searching after we had added the chicken OC-116 sequence to the turkey sequence database produced a single peptide, ${ }_{670}$ QVEQVRHADRLR $_{682}$, matching to the C-terminus (Figure 4). Compared to other OC-116 peptides this peptide was rarely identified and occurred only in very few technical replicates. The distribution of OC-116 peptides over the PAGE slices would rather indicate a turkey OC-116 of a length similar to that of the chicken protein. 
Table 1 The most abundant proteins of turkey eggshell matrix

\begin{tabular}{|c|c|c|c|c|c|}
\hline $\begin{array}{l}\text { ENSMGAP } \\
\text { and } \\
\text { UniProtKB } \\
\text { Accession }\end{array}$ & $\begin{array}{l}\text { Probable } \\
\text { chicken } \\
\text { homolog }\end{array}$ & $\begin{array}{c}\text { Sequence } \\
\text { identity }\end{array}$ & $\begin{array}{l}\text { FASTA } \\
\text { E-value }\end{array}$ & Protein & $\begin{array}{l}\% \text { of } \\
\text { total }^{1}\end{array}$ \\
\hline 00000007641 & IPI00581368 & $79.8 \%$ & $1.9^{-135}$ & Ovocleidin-116 ${ }^{* *}+$ & 31.30 \\
\hline (G1N6E1) & OC116 & & & & \\
\hline 00000004038 & IPI00583974 & $90.9 \%$ & $2.6^{-150}$ & Ovalbumin ** & 12.52 \\
\hline (G1MYK6) & OVAL & & & & \\
\hline 0000015961 & IPI00595980 & $99.2 \%$ & 0 & Periostin & 10.89 \\
\hline (G1NQ91) & F1P4N9 & & & & \\
\hline 00000007759 & IPI00573506 & $78.8 \%$ & $8.8^{-151}$ & Ovocalyxin-36 **+ & 6.00 \\
\hline (G1N6M8) & Q53HW8 & & & & \\
\hline 00000000142 & IPI00600069 & $87.6 \%$ & $1.3^{-68}$ & Extracellular fatty acid-binding protein (EXFAB) ${ }^{* *}$ & 3.82 \\
\hline (G1MQ16) & EXFAB & & & & \\
\hline 0000018878 & IPI00588727 & $77.9 \%$ & $3.7^{-60}$ & EDIL3 **, fragment & 3.70 \\
\hline (G3UT43) & F1NCN3 & & & & \\
\hline 00000018172 & IPI00685019 & $83.2 \%$ & $5.2^{-72}$ & Ig light chains with overlapping peptide sets $* 2$ & 2.81 \\
\hline (G3UR71) & F1NSD0 & & & & \\
\hline etc. & etc. & & & & \\
\hline 00000001491 & IPI00601265 & $86.8 \%$ & $5.0^{-57}$ & Avidin * & 2.67 \\
\hline (G1MSZ9) & AVID & & & & \\
\hline 00000010561 & IPI00574195 & $88.4 \%$ & 0 & Serum albumin ** & 2.57 \\
\hline (G1NCR2) & LBU & & & & \\
\hline 00000002725 & IPI00683271 & $87.3 \%$ & $2.2^{-203}$ & Ovotransferrin ** & 2.22 \\
\hline (G1MVN4) & TRFE & & & & \\
\hline 00000007002 & IPI00576782 & $90.6 \%$ & $2.2^{-56}$ & Cystatin ** & 1.67 \\
\hline (G1N522) & CYT & & & & \\
\hline 0000019196 & IPI00578559 & $76.9 \%$ & $4.0^{-138}$ & Polymeric Ig receptor ${ }^{* *}$, fragment & 1.59 \\
\hline (G3UTW1) & F1NE61 & & & & \\
\hline 00000008902 & IPI00575013 & $95.7 \%$ & $2.2^{-191}$ & Similar to milk fat globule EGF factor 8 protein ${ }^{* *}$ & 1.25 \\
\hline (G1N944) & E1COK5 & & & & \\
\hline 0000015436 & IPI00583503 & $97.6 \%$ & $2.2^{-58}$ & Similar to trefoil family peptide 2 (TFF-2) & 1.13 \\
\hline (G1NP11) & E1BZ37 & & & & \\
\hline 00000002528 & IPI00571581 & $93.1 \%$ & $2.7^{-173}$ & Sulfhydryl oxidase $1^{* *}$ & 1.08 \\
\hline (G1MV84) & QSOX1 & & & & \\
\hline 00000005746 & Q90WR3 & $87.1 \%$ & $1.2^{-76}$ & Hemopexin, fragment ** & 0.80 \\
\hline (H9HOW2) & & & & & \\
\hline 00000005136 & IPI00680258 & $89.3 \%$ & $2.1^{-150}$ & Similar to a2-antiplasmin/serpinF2 ${ }^{*}+$ & 0.80 \\
\hline (G1N0Z7) & F1NAR5 & & & & \\
\hline 00000005175 & IPI00587267 & $97.9 \%$ & $5.7^{-173}$ & Similar to serpinF1/PEDF/a2-antiplasmin ** & 0.64 \\
\hline (G1N131) & $\mathrm{E} 1 \mathrm{C} 7 \mathrm{H} 6$ & & & & \\
\hline 00000010985 & IPI00600859 & $95.2 \%$ & $8.9^{-70}$ & Lysozyme $C^{* *}$ & 0.64 \\
\hline (LYSC) & B8YK79 & & & & \\
\hline 00000017273 & IPI00599414 & $95.9 \%$ & $1.4^{-100}$ & SPARC/BM-40/osteonectin * & 0.57 \\
\hline (G3UNZO) & SPRC & & & & \\
\hline 00000004416 & IPI00573738 & $88.9 \%$ & $5.0^{-120}$ & Ovalbumin-reated protein $Y *$ & 0.43 \\
\hline
\end{tabular}


Table 1 The most abundant proteins of turkey eggshell matrix (Continued)

\begin{tabular}{|c|c|c|c|c|c|}
\hline (G1MZF4) & OVALY & & & & \\
\hline 00000013361 & IPI00595705 & $98.4 \%$ & $1.0^{-54}$ & Similar to epidymal secretory protein E1 * & 0.43 \\
\hline (G1NJ71) & Q5ZJI7 & & & & \\
\hline 00000016597 & IPI00822809 & $77.8 \%$ & $7.5^{-22}$ & Meleagrin (gallin) & 0.42 \\
\hline (G1NRF9) & DGGR58 & & & & \\
\hline 00000004408 & IPI00570865 & $94.4 \%$ & $2.4^{-66}$ & Similar to REG4 * & 0.38 \\
\hline (G1MZE6) & E1BZV4 & & & & \\
\hline 00000007908 & IPI00578482 & $85.6 \%$ & $1.8^{-121}$ & Similar to a-carbonic anhydrase * & 0.35 \\
\hline (G1N6Y5) & E1C004 & & & & \\
\hline 00000014942 & IPI00604279 & $93.9 \%$ & $1.8^{-120}$ & Clusterin ** & 0.31 \\
\hline (G1NMV6) & Q9YGP0 & & & & \\
\hline 000000013859 & IPI00680520 & $93.7 \%$ & $1.9^{-210}$ & Similar to pantetheinase $\mathrm{VNN1}$ * & 0.29 \\
\hline (G1NKC5) & E1BUA6 & & & & \\
\hline 00000001205 & IPI00603434 & $99.0 \%$ & $1.7^{-137}$ & Dentin matrix protein $4 / F A M 20 C{ }^{*}+$ & 0.27 \\
\hline (G1MSD1) & E1C4X0 & & & & \\
\hline 00000016580 & IPI00583184 & $97.3 \%$ & $1.8^{-143}$ & Tsukushin * & 0.25 \\
\hline (G1NRF2) & TSK & & & & \\
\hline 00000010021 & IPI00600561 & $81.2 \%$ & 0 & Chordin ${ }^{*}+$ & 0.24 \\
\hline (G1NBK1) & O57465 & & & & \\
\hline 00000007021 & IPI00573727 & $99.3 \%$ & $1.2^{-115}$ & Similar to nucleobindin- ${ }^{* *}+$ & 0.23 \\
\hline (G1N538) & Q5ZHR1 & & & & \\
\hline 00000008705 & IPI00600003 & $95.2 \%$ & $1.4^{-168}$ & Cathepsin $D^{* *+}$ & 0.22 \\
\hline (G1N8P0) & CATD & & & & \\
\hline 00000015671 & IPI00573323 & $90.0 \%$ & $2.5^{-85}$ & Lysozyme G * & 0.21 \\
\hline (G1NPK6) & LYG & & & & \\
\hline 00000013696 & IPI00585437 & $89.8 \%$ & $1.9^{-47}$ & Similar to prostate stem cell antigen * & 0.18 \\
\hline (G1NJY7) & F1NXM7 & & & & \\
\hline 0000018441 & IPI00594564 & $88.5 \%$ & $1.1^{-133}$ & Similar to nexin-1/serpin E2 ** & 0.18 \\
\hline (G3URX3) & E1BWU2 & & & & \\
\hline 00000009949 & IPI00577639 & 93.9 & $1.2^{-17}$ & Serpin G1/similar to plasma protease C1 inhibitor * & 0.16 \\
\hline \multirow[t]{2}{*}{ (G1NBE9) } & F1NA58 & & & & \\
\hline & (partial) & & & & \\
\hline 00000007635 & IPI00585901 & $93.9 \%$ & $1.7^{-84}$ & Osteopontin ${ }^{*}+$ & 0.15 \\
\hline (G1N6D8) & OSTP & & & & \\
\hline 00000008830 & IPI00585604 & $86.3 \%$ & 0 & Similar to mucin $5 \mathrm{AC} *$ & 0.15 \\
\hline (G1N8Z1) & E1C037 & & & & \\
\hline etc. & etc. & & & & \\
\hline 00000010418 & IPI00573327 & $94.2 \%$ & $1.5^{-208}$ & Vitamin D-binding protein ** & 0.15 \\
\hline (G1NCF1) & Q9W6F5 & & & & \\
\hline 00000003557 & IPI00585935 & $98.0 \%$ & 0 & Similar to semaphorin-3G, fragment * & 0.15 \\
\hline (G1MXI6) & F1NQ93 & & & & \\
\hline 00000010338 & IPI00598054 & $93.1 \%$ & $2.5^{-66}$ & Similar to immunoglobin J chain ** & 0.15 \\
\hline (G1NC90) & E1BY93 & & & & \\
\hline 00000003137 & IPI00590535 & $98.4 \%$ & 0 & Fibronectin, fragment ${ }^{* *}+$ & 0.13 \\
\hline (G1MWJ4) & F1NJT3 & & & & \\
\hline
\end{tabular}


Table 1 The most abundant proteins of turkey eggshell matrix (Continued)

\begin{tabular}{|c|c|c|c|c|c|}
\hline 00000001542 & IPI00587849 & $94.4 \%$ & $6.1^{-154}$ & Similar to antithrombin/serpin C1 ${ }^{*}$ & 0.12 \\
\hline (G1MT40) & F1NLP & & & & \\
\hline 00000002860 & IPI00577696 & $99.0 \%$ & 0 & Uncharacterized protein/similar to glypican-4 ${ }^{* *}+$ & 0.12 \\
\hline (G1MVZO) & F1NAU1 & & & & \\
\hline 00000006152 & IPI00574055 & $99.0 \%$ & 0 & Procollagen-lysine 2-oxoglutarate 5-dioxygenase * & 0.12 \\
\hline (G1N380) & PLOD1 & & & & \\
\hline 0000016417 & IPI00581002 & $100 \%$ & $8.0^{-58}$ & Ubiquitin/polyubiquitin ** & 0.12 \\
\hline (G1NR52) & $\begin{array}{c}\text { F1N4V4 } \\
\text { etc. }\end{array}$ & & & & \\
\hline 00000000900 & IPI00595826 & $99.7 \%$ & 0 & Golgi apparatus protein $1{ }^{*}+$ & 0.11 \\
\hline (G1MRQ6) & $\begin{array}{c}\text { F1P250 } \\
\text { etc. }\end{array}$ & & & & \\
\hline
\end{tabular}

Ovocleidin-17 (OC-17) is a major chicken eggshell protein [8] completely unrelated to OC-116 [47,48]. Its amino acid sequence was established by Edman sequence analysis of the purified protein [48]. The presence of a C-type lectin-like domain lacking the characteristics of a typical true C-type lectin and a tendency to aggregate during isolation suggested a function as structural matrix protein [48]. However, OC-17 was also reported to affect in vitro calcium carbonate crystallization [49] and to possess antimicrobial activity [50]. Neither the genome-derived protein sequence database of turkey nor that of chicken contained a sequence of significant similarity to OC-17, indicating that it may be encoded in the $5-10 \%$ of the genome sequences still missing for both species [23]. Addition of the chicken $\mathrm{OC}-17$ protein sequence to the turkey protein sequence database yielded two OC-17 peptides, ${ }_{47}$ SAAELRLLAELLNASR $_{62}$ and ${ }_{75} \mathrm{VWIGLHR}_{81}$ (Figure 5). Furthermore, the existence of a protein similar to $\mathrm{OC}-17$ in turkey eggshell matrix would be in agreement with the results of a comparative Western blotting study using anti-chicken OC-17 antiserum [51]. The OC-17 peptides peaked in gel fractions 15 and 16 (Additional files 2: Table S2 and Additional file 3: Table S3), corresponding to the size of OC-17. However, major proteins of similar size, such as avidin and cystatin, also showed a peak of their peptide distribution in these same fractions and very likely correspond to the two major bands observed in these sections (Figure 1). Nevertheless, the sum of evidence may indicate that $\mathrm{OC}-17$ is present in turkey eggshell matrix, although at an unknown percentage of the total proteome.

Ovocalyxin-36 (OCX-36) is a major protein of the turkey eggshell matrix proteome (Table 1) and the chicken eggshell matrix proteome [8]. In chicken it is secreted in oviduct sections where eggshell production takes place and its gene expression is strongly upregulated during mineralization [19,52]. Its sequence contains a bactericidal permeability-increasing domain and OCX-36 was therefore suggested to play a role in egg defense against microbial contamination [52].

Two other ovocalyxins, OCX-32 and OCX-21 were not found in the turkey eggshell matrix proteome. OCX32 [53] apparently did not have a counterpart in the published turkey genome sequence. Addition of the chicken protein sequence to the turkey sequence database used with MaxQuant did not produce any evidence for its presence in the turkey eggshell matrix. OCX-21 is a name given to the sequence contained in entry IPI00574331 of the chicken sequence database on various occasions $[17,19])$ and is identical to gastrokine-2 (E1C2G7_CHICK), a secretory protein of mammalian gastric surface mucous cells [54]. FASTA database searches showed that the turkey protein sequence database did contain a homolog of the protein with $92.5 \%$ sequence identity to the chicken protein in accession ENSMGAP00000000035/G1MPS6 _MELGA. Therefore, the absence of any identified peptide of this major chicken eggshell matrix protein [8] may indicate its absence from the turkey eggshell matrix.

\section{Major proteins not previously identified in eggshells}

Among the major turkey eggshell matrix proteins (Table 1) were two proteins that were not identified in other eggshell matrices or egg fractions before, periostin and trefoil family peptide 2 (TFF-2). Periostin accounted for almost $11 \%$ of the total matrix proteome and was not identified in the chicken matrix although a periostin sequence was present in the IPI_CHICK sequence database used for this study [8]. As expected from its name, 


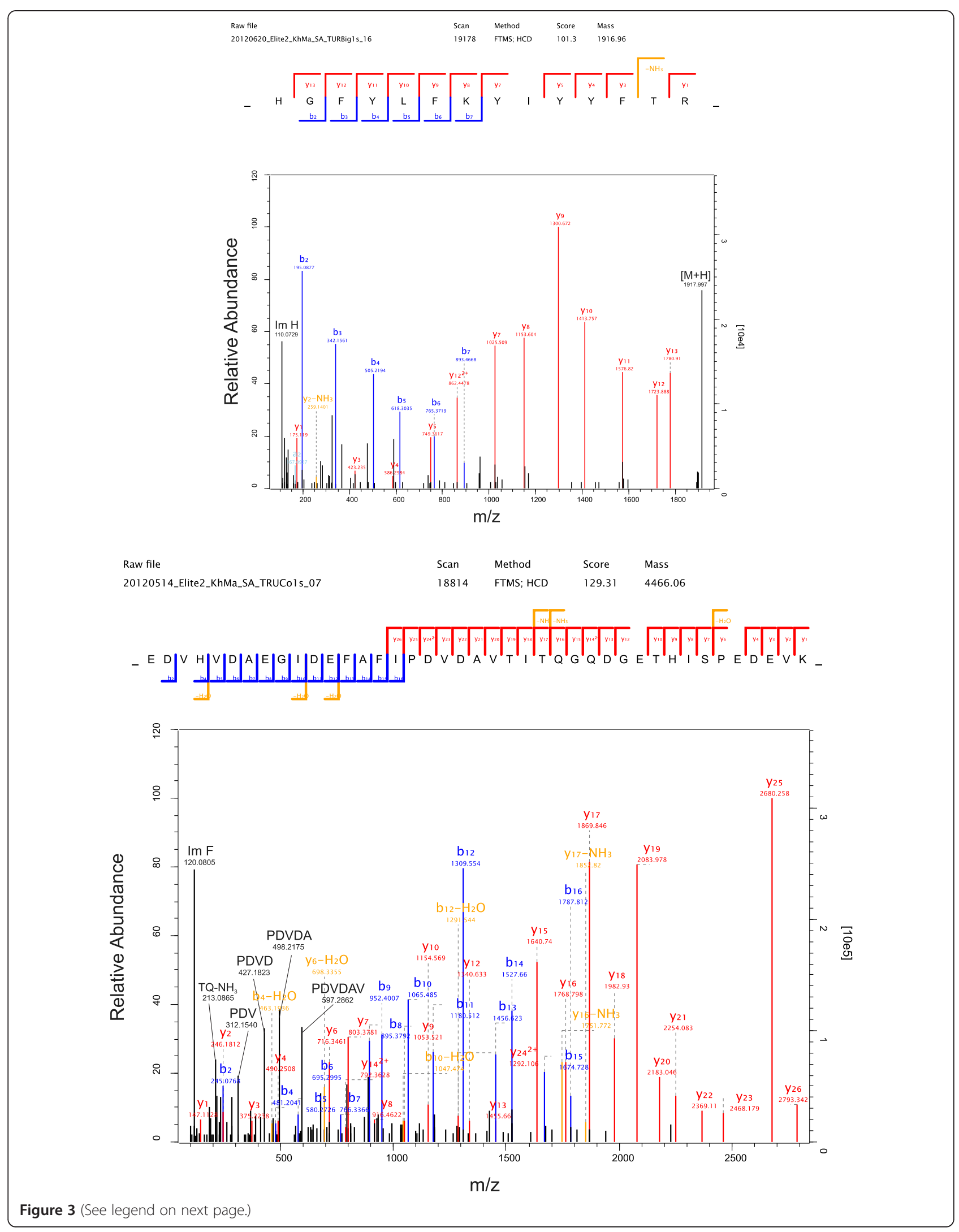


(See figure on previous page.)

Figure 3 Representative spectra of turkey ovocleidin-116 (ENSMGAP00000007641/G1N6E1) peptides. Top, doubly charged peptide (aa4659) with PEP $2.4^{-15}$ and a mass error of -1.0 ppm. Bottom, quintuply charged peptide (aa234-273) with PEP $8.5^{-215}$ and a mass error of $-0.2 \mathrm{ppm}$. MaxQuant Expert System annotations not contained in simple fragment annotation were added for some major peaks (in black). These were the $[\mathrm{M}+\mathrm{H}]$ ion and the histidine immonium ion in the upper spectrum and a series of internal fragments and the phenylalanine immonium ion in the lower spectrum. Full expert annotation is not shown for sake of clarity.

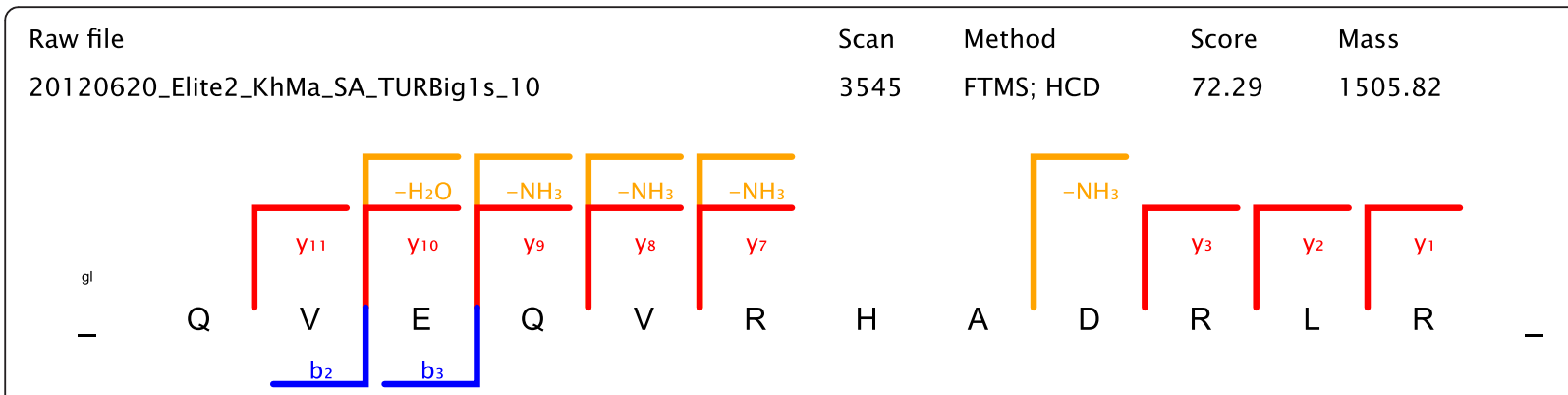

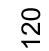

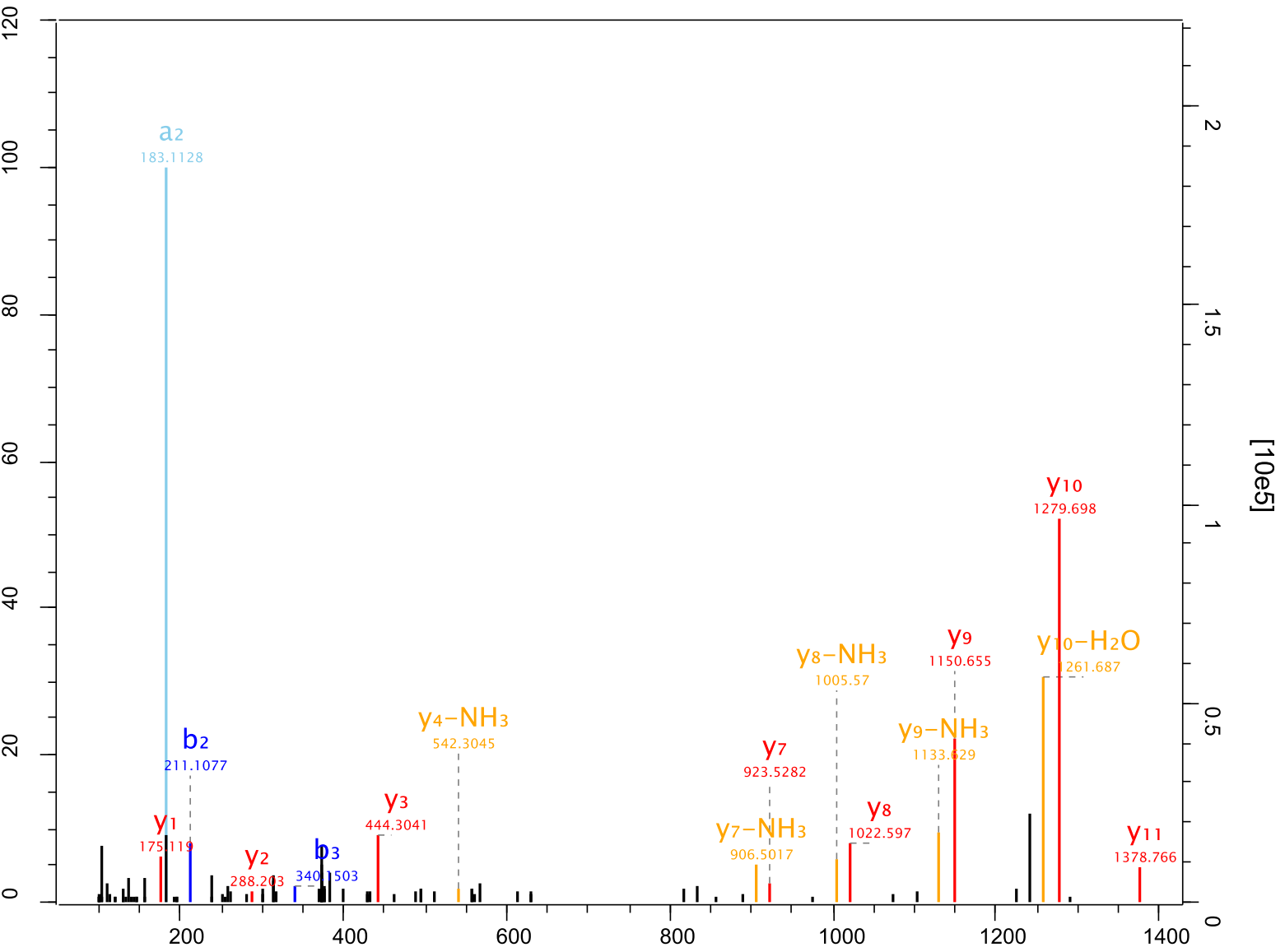

Figure 4 Spectrum of a turkey OC-116 peptide indicating the presence of a C-terminus similar to chicken OC-116. This peptide was not found in turkey OC-117 but matches the chicken OC-116 C-terminus (aa671-682), which is missing in the turkey protein. This quadruply charged peptide was identified with a posterior error probability (PEP) of 0.0005 and a mass error of $-0.144 \mathrm{ppm}$. It is the only evidence for the presence in the turkey protein of a C-terminus similar to that of chicken OC-116. The N-terminal glutamine was cyclized to pyroglutamate during peptide fractionation under acidic conditions, a frequently observed modification of peptides with $\mathrm{N}$-terminal glutamine. 

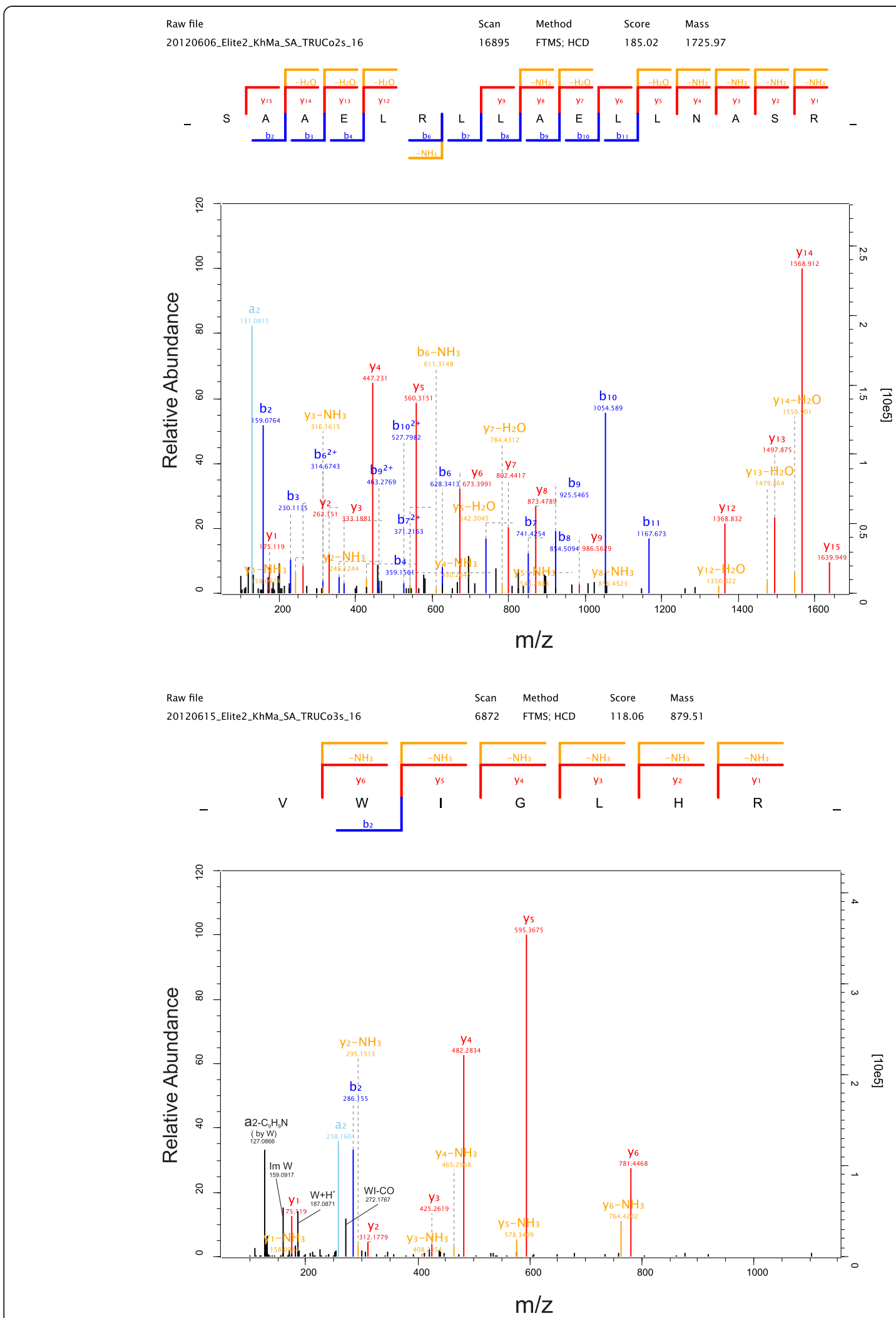

Figure 5 (See legend on next page.) 
periostin was detected in the periosteum that covers the outer surface of bone, but it also occurs in other collagen-rich mammalian connective tissues [55]. The role of periostin in bone mineralization is not clear at present, although it seems to be important for bone growth and repair, and there is no indication of its possible function in eggshell formation at present. Its presence in shell matrix now provides another strong link of eggshell mineralization to bone metabolism.

TFF-2 belongs to a family of small proteins expressed predominantly in the mucosa of the gastrointestinal tract $[56,57]$ and it seems to play a role in mucosal protection and repair. Its location and function in the mammalian gastrointestinal tract apparently partially overlaps with that of gastrokines such as OCX-21/gastrokine-2. Indeed interactions between gastrokines and TFFs have been reported [54]. TFF-2 binds to mucins, especially to mucin 5AC [58], which was another major component of the major turkey eggshell (Table 1). In vitro binding of TFF-2 to mucin induces the formation of highly viscous complexes [59]. Thus, the function of these two matrix components may be to protect the shell gland mucosa of egg-laying hens.

Also not previously identified in eggshell matrix was the egg white protein meleagrin [60]. Its chicken homolog gallin was shown to have antimicrobial activity [61]. The expression of gallin was highest in the magnum section of the oviduct and about 140 times less in the eggshell gland. This indicates that this small protein reaches the eggshell gland essentially as a left-over of egg white assembly by co-migration through the oviduct together with the unfinished egg [61].

\section{Other major proteins possibly involved in mineralization or matrix assembly of chicken and turkey}

Osteopontin is a major non-collagen protein in bone but also occurs in many other tissues and body fluids. It has an inhibitory effect on various normal and pathological mineralization processes [62]. In the chicken oviduct it is secreted exclusively in the eggshell gland and accumulates in the shell matrix [13]. Osteopontin of different species is highly phosphorylated and its inhibitory effect was shown to depend on phosphorylation. Similar to chicken osteopontin $[8,9]$ the abundance of turkey osteopontin was most probably greatly underestimated because the phosphorylated peptides were not identified in this general survey. The kinase phosphorylating extracellular matrix proteins such as OC-116 and osteopontin was recently identified as FAM20C protein $[63,64]$, a Golgi lumen resident that was also found in chicken and turkey eggshell matrix (Table 1). Another obvious candidate for a protein with a role in mineralization is G1N6Y5_MELGA, which contains a predicted $\alpha$ carbonic anhydrase domain and could therefore be involved in carbonate production for the growing eggshell calcite layer or the control of $\mathrm{CO}_{2}$ concentration in the uterus fluid. A protein with a probable, yet unknown, function in eggshell assembly is glypican-4 (Table 1). Similar to the expression of osteopontin [65] its expression is massively up-regulated in response to the mechanical strain exerted onto the eggshell gland walls upon entry of the egg and ceases shortly before completion of the eggshell [66]. Other proteins may have a more general function in eggshell matrix production, such as the extracellular chaperone clusterin, which may be important in maintaining the proper folding of matrix proteins during matrix assembly [67]. SPARC/BM40/osteonectin, which is also abundant in other vertebrate mineralized tissues such as bone and teeth, may participate in regulation of matrix assembly [68].

\section{Major egg white proteins in the eggshell matrix}

Major egg white proteins known from chicken that were identified among the major turkey eggshell matrix proteins were ovalbumin, avidin, ovotransferrin, cystatin and lysozyme $C$ (Table 1). Many others were identified at lower abundance (Additional file 1: Table S1). Two of the major proteins, lysozyme $\mathrm{C}$ and ovotransferrin were shown to be true components of the chicken eggshell matrix previous to proteomic analyses using immunohistochemical methods [11,12]. Several of these proteins have antimicrobial activity and their main function during egg production may be in the defense of egg and oviduct against microbial contamination either by direct attack of bacterial cell walls (lysozyme C), iron sequestration (ovotransferrin), biotin sequestration (avidin), or protease inhibition (cystatin) $[1,2]$. Lysozyme $\mathrm{C}$, ovotransferrin, and ovalbumin have a very weak effect on calcium carbonate crystal morphology in vitro $[11,12,14,15]$ but their possible role in in vivo crystallization, if any, remains unclear at present. An attractive idea in this respect is that such proteins showing only very weak or no interaction with calcite may nevertheless influence eggshell mineralization by 
maintaining a proper environment in the eggshell gland with respect to $\mathrm{pH}, \mathrm{CO}_{2}$ concentration and soluble calcium availability in the uterus fluid [14].

\section{Conclusions}

Analysis of the turkey eggshell matrix proteome revealed some unexpected differences as compared to the chicken eggshell matrix, although both species belong to the same family (Phasianidae). The turkey eggshell contains a new major eggshell component, the bone protein periostin. There were also differences among a group of so-called eggshell-specific proteins produced in the chicken eggshell gland epithelial cells and thought to be very important for eggshell production. Two of these, OC-116 and OCX-36, were also among the major turkey eggshell matrix proteins. Another one, OCX-21/gastrokine-2 was missing in the proteome, although a very similar protein sequence was contained in the genome-derived turkey protein sequence database. The sequences of OC-17 and OCX-32 were not contained in the turkey sequence database but may be encoded in the $5-10 \%$ of the genome not yet sequenced [22,23]. Addition of the chicken sequences of these two proteins to the database enabled identification of two OC-17 peptides suggesting the presence of this protein in the turkey eggshell matrix. However, this approach was not successful in the case of OCX-32, indicating that it either was not in the matrix or that the sequences are too different for such a cross-species identification. More eggshell proteomes are needed to identify a possible common set of shell mineralization-controlling avian proteins along with more transcriptome studies, immunochemical approaches to eggshell protein localization, and functional tests with isolated proteins.

\section{Additional files}

Additional file 1: Table S1. This table shows the complete list of accepted protein identifications in turkey eggshell matrix preparations.

Additional file 2: Table S2. ProteinGroups pool A. This file shows the MaxQuant-derived protein identification data for pool A (strain Converter), such as additional accession numbers for protein groups, protein scores, number of peptides, distribution of peptides in gel slices and molecular weight of the predicted protein.

Additional file 3: Table S3. ProteinGroups pool B. MaxQuant-derived protein data for pool B (strain Big6).

Additional file 4: Table S4. Peptides pool A. MaxQuant list of peptides identified in pool A (strain Converter). This Excel sheet contains all peptide sequences in alphabetic order and relevant parameters, such as preceding amino acid, peptide charge, peptide mass, scores, PEP value, distribution in gel slices, and BBAQ intensities

Additional file 5: Table S5. Peptides pool B. MaxQuant list of peptides identified in pool B (strain Big6).

\section{Abbreviations}

Aa: Amino acid; FDR: False discovery rate; HCD: Higher-energy collisioninduced dissociation; iBAQ: Intensity-based absolute quantification;
OC: Ovocleidin; OCX: Ovocalyxin; PAGE: Polyacrylamide gel electrophoresis; PEP: Posterior error probability; TFF: Trefoil family of proteins.

Competing interests

The authors declare that they have no competing interests.

\section{Authors' contributions}

KM conceived the study, performed sample preparation and data acquisition. MM supplied methodological expertise. Both authors took part in the design of the study and were critically involved in manuscript drafting. All authors read and approved the final manuscript.

Received: 25 July 2013 Accepted: 23 August 2013

Published: 27 August 2013

\section{References}

1. Burley RW, Vadhera DV: The avian egg. Chemistry and Biology. New York: John Wiley and Sons; 1989.

2. Mine Y: Egg bioscience and biotechnology. Hoboken, New Jersey: John Wiley and Sons; 2008.

3. Schneider WJ, Osanger A, Waclawek M, Nimpf J: Oocyte growth in the chicken. Receptors and more. Biol Chem 1998, 379:965-971.

4. Creger CR, Phillips H, Scott JT: Formation of an eggshell. Poult Sci 1976, 55:1717-1723

5. Rose MLH, Hincke MT: Protein constituents of the eggshell: eggshellspecific matrix proteins. Cell Mol Life Sci 2009, 66:2707-2719.

6. Hincke MT, Nys Y, Gautron J: The role of matrix proteins in eggshell formation. J Poult Sci 2010, 47:208-219.

7. Hincke MT, Nys Y, Gautron J, Mann K, Rodriguez-Navarro AB, McKee MD: The eggshell: structure, composition and mineralization. Front Biosci 2012, 17:1266-1280.

8. Mann K, Macek B, Olsen JV: Proteomic analysis of the acid-soluble organic matrix of the chicken calcified eggshell layer. Proteomics 2006, 6:3801-3810.

9. Mann K, Olsen JV, Macek B, Gnad F, Mann M: Phosphoproteins of the chicken eggshell calcified layer. Proteomics 2007, 7:106-115.

10. Hincke MT: Ovalbumin is a component of the chicken eggshell matrix. Connect Tissue Res 1995, 31:227-233.

11. Hincke MT, Gautron J, Panheleux M, Garcia-Ruiz J, McKee MD, Nys Y: Identification and localization of lysozyme as a component of eggshell membranes and eggshell matrix. Matrix Biol 2000, 19:443-453.

12. Gautron J, Hincke MT, Panhéleux M, Garcia-Ruiz JM, Boldicke T, Nys Y: Ovotransferrin is a matrix protein of the hen eggshell membranes and basal calcified layer. Connective Tissue Res 2001, 42:255-267.

13. Pines M, Knopov V, Bar A: Involvement of osteopontin in egg shell formation in the laying chicken. Matrix Biol 1994, 14:765-771.

14. Hernández-Hernández A, Gómez-Morales J, Rodríquez-Navarro AB, Gautron J, Nys Y, García-Ruiz JM: Identification of some active proteins in the process of hen eggshell formation. Crystal Growth \& Design 2008, 8:4330-4339.

15. Hernández-Hernández A, Vidal M-L, Gómez-Morales J, Rodríguez-Navarro AB, Labas V, Gautron J, Nys Y, García-Ruiz JM: Influence of eggshell matrix proteins on the precipitation of calcium carbonate. Journal of Crystal Growth 2008, 310:1754-1759.

16. Miksik I, Sedlakova P, Lacinova K, Pataridis S, Eckardt A: Determination of insoluble avian eggshell matrix proteins. Anal Bioanal Chem 2010, 397:205-214.

17. Rose-Martel M, Du J, Hincke MT: Proteomic analysis provides new insight into the eggshell cuticle. J Proteom 2012, 75:2697-2706.

18. Dunn IC, Wilson PW, Lu Z, Bain MM, Crossan CL, Talbot RT, Waddington D: New hypotheses on the function of the avian shell gland derived from microarray analysis comparing tissue from juvenile and sexually mature hens. Gen Comp Endocrinol 2009, 163:225-232.

19. Jonchère V, Réhaut-Godbert S, Hennequet-Antier C, Cabau C, Sibut V, Cogburn LA, Nys Y, Gautron J: Gene expression profiling to identify eggshell proteins involved in physical defence of the chicken egg. BMC Genomics 2010, 11:57.

20. International Chicken Genome Sequencing Consortium: Sequence and comparative analysis of the chicken genome provide unique perspectives on vertebrate evolution. Nature 2004, 432:695-716. 
21. Warren WC, Clayton DF, Ellegren $H$, Arnold AP, Hillier LD, Künstner $A$, Searle S, White S, Vilella AJ, Fairley S, Heger A, Kong L, Ponting CP, Jarvis ED, Mello CV, Minx P, Lovell P, Velho TAF, Ferris M, Balakrishnan CN, Sinha S, Blatti C, London SE, Li Y, Lin Y-C, George J, Sweedler J, Southey B, Gunaratne P, Watson M, Nam K, Backström N, Smeds L, Nabholz B, Itoh Y, Whitney O, Pfenning AR, Howard J, Völker M, Skinner BM, Griffin DK, Ye L, McLaren WM, Flicek P, Quesada V, Velasco G, Lopez-Otin C, Puente XS, Olender T, Lancet D, Smit AFA, Hubley R, Konkel MK, Walker JA, Batzer MA, Gu W, Pollock DD, Chen L, Cheng Z, Eichler EE, Stapley J, Slate J, Ekblom R, Birkhead T, Burke T, Burt D, Scharff C, Adam I, Richard H, Sultan M, Soldatov A, Lehrach H, Edwards SV, Yang S-P, Li XC, Graves T, Fulton L, Nelson J, Chinwalla A, Hou S, Mardis ER, Wilson RK: The genome of a songbird. Nature 2010 464:757-762.

22. Dalloul RA, Long JA, Zimin AV, Aslam L, Beal K, Blomberg L, Bouffard P, Burt DW, Crasta O, Crooijmans RPMA, Cooper K, Coulombe RA, De S, Delany ME, Dodgson JB, Dong JJ, Evans C, Frederickson KM, Flicek P, Florea L, Folkerts O, Groenen MAM, Harkins TT, Herrero J, Hoffmann S, Megens HJ, Jiang A, de Jong P, Kaiser P, Kim H, Kim KW, Kim S, Langenberger D, Lee MK, Lee T, Mane S, Marcais G, Marz M, McElroy AP, Modise T, Nefedov M, Notredame C, Paton IR, Payne WS, Pertea G, Prickett D, Puiu D, Qioa D, Raineri E, Ruffier M, Salzberg SL, Schatz MC, Scheuring C, Schmidt CJ, Schroeder S, Searle SMJ, Smith EJ, Smith J, Sonstegard TS, Stadler PF, Tafer H, Tu ZJ, Van Tassell CP, Vilella AJ, Williams KP, Yorke JA, Zhang LQ, Zhang HB, Zhang XJ, Zhang $Y$, Reed KM: Multi-platform next-generation sequencing of the domestic turkey (Meleagris gallopavo): genome assembly and analysis. PLOS Biology 2010, 8:e1000475.

23. Dodgeson JB, Delany ME, Cheng HH: Poultry genome sequences: progress and outstanding challenges. Cytogenet Genome Res 2011, 134:19-26.

24. Shevchenko A, Tomas H, Havlis J, Olsen JV, Mann M: In-gel digestion for mass spectrometric characterization of proteins and proteomes. NatureProtocols 2006, 1:2856-2860.

25. Rappsilber J, Mann M, Ishihama Y: Protocol for micro-purification, enrichment, pre-fractionation and storage of peptides for proteomics using StageTips. Nat Protoc 2007, 2:1896-1906.

26. Michalski A, Damoc E, Lange O, Denisov E, Nolting D, Müller M, Viner R, Schwartz J, Remes P, Belford M, Dunyach J-J, Cox J, Horning S, Mann M, Makarov A: Ultra high resolution linear ion trap orbitrap mass spectrometer (Orbitrap Elite) facilitates top down LC MS/MS and versatile peptide fragmentation modes. Mol Cell Proteomics 2012, $11: 1-11$.

27. Michalski A, Neuhauser N, Cox J, Mann M: A systematic investigation into the nature of tryptic HCD spectra. J Proteome Res 2012, 11:5479-5491.

28. Cox J, Mann M: MaxQuant enables high peptide identification rates, individualized ppb-range mass accuracies and proteome-wide protein quantification. Nature Biotechnol 2009, 26:1367-1372.

29. Cox J, Matic I, Hilger M, Nagaraj N, Selbach M, Olsen JV, Mann M: A practical guide to the MaxQuant computational platform for SILACbased quantitative proteomics. Nat Protoc 2009, 4:698-705.

30. Cox J, Neuhauser N, Michalski A, Scheltema RA, Olsen JV, Mann M: Andromeda - a peptide search engine integrated into the MaxQuant environment. J Proteome Res 2011, 10:1794-1805.

31. Neuhauser N, Michalski A, Cox J, Mann M: Expert system for computerassisted annotation of MS/MS spectra. Mol Cell Proteom 2012, 11:1500-1509.

32. Schwanhäusser B, Busse D, Li N, Dittmar G, Schuchhardt J, Wolf J, Chen W, Selbach M: Global quantification of mammalian gene expression control. Nature 2011, 473:337-342.

33. Goujon M, McWilliam H, Li W, Valentin F, Squizzato S, Paern J, Lopez R: A new bioinformatics analysis tools framework at EMBL-EBI (2010). Nucleic Acids Res 2010, 38(Suppl):W695-9

34. Hunter $\mathrm{S}$, Jones $\mathrm{P}$, Mitchell A, Apweiler R, Attwood TK, Bateman A, Bernard

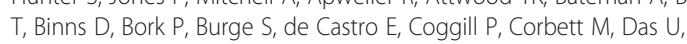
Daugherty L, Duquenne L, Finn RD, Fraser M, Gough J, Haft D, Hulo N, Kahn D, Kelly E, Letunic I, Lonsdale D, Lopez R, Madera M, Maslen J, McAnulla C, McMenamin C, Mi H, Mutowo-Muellenet P, Mulder N, Natale D, Orengo C, Pesseat S, Punta M, Quinn AF, Rivoire C, Sangrador-Vegas A, Selengut JD, Sigrist CJA, Scheremetjew M, Tate J, Thimmajanarthanan M, Thomas PD, Wu $\mathrm{CH}$, Yeats C, Yong S-Y: InterPro in 2011: new developments in the family and domain prediction database. Nucleic Acids Res 2011, 40:D306-D312.

35. Petersen TN, Brunak S, von Heinje G, Nielsen H: SignalP 4.0: discriminating signal peptides from transmembrane regions. Nat Methods 2011, 8:785-786.
36. Ishihama Y, Oda Y, Tabata T, Sato T, Nagasu T, Rappsilber J, Mann M: Exponentially modified protein abundance index (emPAl) for estimation of absolute protein amount in proteomics by the number of sequenced peptides per protein. Mol Cell Proteomics 2005, 4:1265-1272.

37. Mann K, Hincke MT, Nys Y: Isolation of ovocleidin-116 from chicken eggshells, correction of its amino acid sequence and identification of disulfide bonds and glycosylated Asn. Matrix Biol 2002, 21:383-387.

38. Carrino DA, Rodriguez JP, Caplan Al: Dermatan sulfate proteoglycans from the mineralized matrix of the avian eggshell. Connect Tissue Res 1997, 36:175-193.

39. Hincke MT, Gautron J, Tsang CP, McKee MD, Nys Y: Molecular cloning and ultrastructural localization of the core protein of an eggshell matrix proteoglycan, ovocleidin-116. J Biol Chem 1999, 274:32915-32923.

40. Nimtz M, Conradt HS, Mann K: LacdiNAc (GalNAcß1-4GIcNAc) is a major motif in $\mathrm{N}$-glycan structures of the chicken eggshell protein ovocleidin116. Biochim Biophys Acta 2004, 1675:71-80

41. Mann K, Mann M: The chicken egg yolk plasma and granule proteomes. Proteomics 2008, 8:178-191.

42. Mann K: Proteomic analysis of the chicken egg vitelline membrane. Proteomics 2008, 8:2322-2332.

43. Mann K, Mann M: In-depth analysis of the chicken egg white proteome using an LTQ orbitrap Velos. Proteome Sci 2001, 9:7.

44. Horvat-Gordon M, Yu F, Burns D, Leach RM: Ovocleidin (OC 116) is present in avian skeletal tissues. Poult Sci 2008, 87:1618-1623.

45. Bardet C, Vincent C, Lajarille M-C, Jaffredo T, Sire J-Y: OC-116, the chicken ortholog of mammalian MEPE found in eggshell, is also expressed in bone cells. J Exp Zool 2010, 314B:653-662.

46. Staines KA, Mackenzie NCW, Clarkin CE, Zelenchuk L, Rowe PS, MacRae VE, Farquharson C: MEPE is a novel regulator of growth plate cartilage mineralization. Bone 2012, 51:418-430.

47. Hincke MT, Tsang CPW, Courtney M, Hill V, Narbaitz R: Purification and immunochemistry of a soluble matrix protein of the chicken eggshel (ovocleidin-17). Calcif Tissue Int 1995, 56:578-583.

48. Mann K, Siedler F: The amino acid sequence of ovocleidin-17, a major protein of the avian eggshell calcified layer. Biochem Mol Biol Int 1999, 47:997-1007.

49. Reyes-Grajeda JP, Moreno A, Romero A: Crystal structure of ovocleidin-17, a major protein of the calcified Gallus gallus eggshell. J Biol Chem 2004, 279:40876-40881.

50. Wellman-Labadie O, Lakshminarayanan R, Hincke MT: Antimicrobial properties of avian eggshell-specific C-type lectin-like proteins. FEBS Lett 2008, 582:699-704.

51. Panhéleux M, Bain M, Fernandez MS, Morales I, Gautron J, Arias JL, Solomon SE, Hincke MT, Nys Y: Organic matrix composition and ultrastructure of eggshell: a comparative study. Brit Poult Sci 1999, 40:240-252.

52. Gautron J, Murayama E, Vignal A, Morisson M, McKee MD, Réhault S, Labas V, Belghazi M, Vidal M-L, Nys Y, Hincke MT: Cloning of ovocalyxin-36, a novel chicken eggshell protein related to lipopolysaccharide-binding proteins, bactericidal permeability-increasing proteins, and Plunc family proteins. J Biol Chem 2007, 282:5273-5286.

53. Gautron J, Hincke MT, Mann K, Panhéleux M, Bain M, McKee MD, Solomon SE, Nys Y: Ovocalyxin-32, a novel chicken eggshell matrix protein. J Biol Chem 2001, 276:39243-39252.

54. Menheniott TR, Kurklu B, Giraud AS: Gastrokines: stomach-specific proteins with putative homeostatic and tumor suppressor roles. Am J Physiol Gastrointest Liver Physiol 2013, 304:G109-G121.

55. Merle B, Garnero P: The multiple facets of periostin in bone metabolism. Osteoporos Int 2012, 23:1199-1212.

56. Kjellev S: The trefoil factor family - small peptides with multiple functionalities. Cell Mol Life Sci 2009, 66:1350-1369.

57. Jiang Z, Lossie AC, Applegate TJ: Evolution of trefoil factor(s): Genetic and spatio-temporal expression of trefoil factor 2 in the chicken (Gallus gallus domesticus). PlosOne 2001, 6:e22691.

58. Kouznetsova I, Laubinger W, Kalbacher H, Kalinski T, Meyer F, Roessner A, Hoffman W: Biosynthesis of gastrokine-2 in the human gastric mucosa: restricted spatial expression along the antral gland axis and differential interaction with TFF1, TFF2 and mucins. Cell Physiol Biochem 2007, 20:899-908

59. Thim L, Madsen F, Poulsen SS: Effect of trefoil factors on the viscoelastic properties of mucus gels. Eur J Clin Invest 2002, 32:519-527. 
60. Odani S, Koide T, Ono T, Takahashi Y, Suzuki J: Covalent structure of a lowmolecular mass protein, meleagrin, present in turkey (Meleagris gallopavo) ovomucoid preparation. J Biochem 1989, 105:660-663.

61. Gong D, Wilson PW, Bain MM, McDade K, Kalina J, Hérve-Grépinet V, Nys Y, Dunn IC: Gallin, an antimicrobioal peptide member of a new avian defensing family, the ovodefensins, has been subject to recent gene duplication. BMC Immunol 2010, 11:12.

62. Staines KA, MacRae VE, Farquharson C: The importance of the SIBLING family of proteins on skeletal mineralization and bone remodeling. J Endocrinol 2012, 214:241-255.

63. Ishikawa HO, Xu A, Ogura E, Manning G, Irvine KD: The Raine syndrome protein FAM20C is a Golgi kinase that phosphorylates biomineralization proteins. PLOS ONE 2012, 7:e42988.

64. Tagliabracci VS, Engel JL, Wen J, Wiley SE, Worby CA, Kinch LN, Xiao J, Grishin NV, Dixon JE: Secreted kinase phosphorylates extracellular proteins that regulate biomineralization. Science 2012, 336:1150-1153.

65. Lavelin I, Yarden N, Ben-Bassat S, Bar A, Pines M: Regulation of osteopontin expression during egg shell formation in the laying hen by mechanical strain. Matrix Biol 1998, 17:615-623.

66. Lavelin I, Meiri N, Einat M, Genina O, Pines M: Mechanical strain regulation of the chicken glypican-4 gene expression in the avian eggshell gland. Am J Physiol Regul Integr Comp Physiol 2002, 283:R855-R861.

67. Mann K, Gautron J, Nys Y, McKee MD, Bajari T, Schneider WJ, Hincke MD: Disulfide-linked heterodimeric clusterin is a component of the chicken eggshell matrix and egg white. Matrix Biol 2003, 22:397-407.

68. Kawasaki K, Buchanan AV, Weiss KM: Biomineralization in humans: Making the hard choices of life. Annu Rev Genet 2009, 43:1 19-142.

doi:10.1186/1477-5956-11-40

Cite this article as: Mann and Mann: The proteome of the calcified layer organic matrix of turkey (Meleagris gallopavo) eggshell. Proteome Science 2013 11:40

\section{Submit your next manuscript to BioMed Central and take full advantage of:}

- Convenient online submission

- Thorough peer review

- No space constraints or color figure charges

- Immediate publication on acceptance

- Inclusion in PubMed, CAS, Scopus and Google Scholar

- Research which is freely available for redistribution 